\title{
Juízo e Opinião em Hannah Arendt*
}

\author{
Hannah Arendt on Judgement and Opinion
}

\author{
Yara Frateschi \\ yfrateschi@gmail.com \\ (Universidade Estadual de Campinas, São Paulo, Brasil)
}

\begin{abstract}
Resumo: A primeira parte deste texto reconstrói a história da filosofia política, tal como contada por Hannah Arendt a partir de alguns dos seus personagens principais: Platão, Hegel e Marx. A despeito dos distintos contextos, problemas e eventos aos quais respondem, estes filósofos apresentam um traço comum: a fuga da política e a hostilidade contra a pluralidade humana. Trata-se de mostrar que, para Arendt, a possibilidade de uma nova filosofia política depende desse exercício de submeter a filosofia política ocidental a uma crítica radical. A segunda parte analisa as soluções filosóficas que Arendt apresenta na sua tentativa de reconciliar a filosofia com a política no que diz respeito a dois temas centrais e interligados: a formação do juízo e da opinião. A formação dialógica e intersubjetiva de opinião (que Arendt formula com Sócrates) e o pensamento representativo (que Arendt formula com Kant) são, na minha interpretação, dois dos momentos mais potentes da sua obra, capazes de fornecer insights preciosos para a constante atualização do seu pensamento político.
\end{abstract}

Palavras-chave: Hannah Arendt; filosofia política; pluralidade; juízo; opinião.

\begin{abstract}
The first part of this paper reconstructs the history of political philosophy as narrated by Hannah Arendt, starting with some of her main characters: Platão, Hegel, and Marx. Despite relating to different contexts, problems and events, these philosophers carry a common trait: the avoidance of politics and the hostility to human pluralism. I intend to demonstrate that, for Arendt, the possibility of a renewed political philosophy depends on this exercise of subjecting Western political philosophy to a radical criticism. The second part analyses the philosophical solutions presented by Arendt in an attempt of reconciliation between philosophy and politics regarding two central themes that are intertwined: the formation of judgment and opinion. The dialogic and intersubjective formation of opinion (which Arendt formulates with reference to Socrates) and the representative thinking (that she formulates referring to Kant) are, in my interpretation, two of the most potent moments of her work, capable of providing precious insights for the ongoing updating of her political thought.
\end{abstract}

Keywords: Hannah Arendt; political philosophy; pluralism; judgment; opinion.

DOI: http://dx.doi.org/10.11606/issn.2318-9800.v24i1p35-65

“A tradição de nosso pensamento político teve seu início definido nos ensinamentos de Platão e Aristóteles. Creio que ela chegou a um fim não menos definido com as teorias de Karl Marx" (Arendt, 1992, p.43). A primeira parte deste texto reconstrói a história da filosofia política, tal como contada por Hannah Arendt

* Agradeço especialmente a Paulo Bodziak Junior por ter me feito compreender a importância do manuscrito "Philosophy and Politics: the problem of action and thought after the French Revolution" de 1954, a Renata Romolo Brito pela tradução cuidadosa das passagens do manuscrito que constam neste artigo em português e a Monique Hulshof pela leitura atenta e discussão da versão final. 
a partir de alguns dos seus personagens principais: Platão, Hegel e Marx. Trata-se de acompanhar a narrativa da "biografia do filósofo" que Arendt nos apresenta. Se é possível narrá-la como a biografia do filósofo é porque, a despeito dos distintos contextos, problemas e eventos aos quais as suas filosofias respondem, estes filósofos apresentam um traço comum: a fuga da política e a hostilidade contra a pluralidade humana. De Platão a Marx, a filosofia política não é capaz de lidar com as fragilidades e incertezas inerentes aos assuntos humanos e o modo que encontra de enfrentá-las é abolindo o fato de que as pessoas, os agentes, existem no plural. Mas filósofos, por mais sofisticados que sejam, não conseguem abolir fatos, muito menos a condição humana da pluralidade: seria preciso, para tanto, deter a possibilidade do nascimento. Defendo que narrar a "biografia do filósofo" é, para Arendt, um exercício de submeter a filosofia política ocidental a uma crítica radical da qual depende a possibilidade de uma nova filosofia política. Para abandonar a hostilidade com relação aos assuntos humanos, os filósofos precisariam fazer da pluralidade humana - responsável pela nossa grandeza e pela nossa miséria - "o objeto do seu espanto" (Arendt, 1954, imagem 70).

Relaciona-se diretamente com a hostilidade típica do filósofo contra a pluralidade humana o desprezo ou a negligência pela ação e a preferência "pela atividade muito mais confiável do fazer" (Arendt, 1992, p.119). Platão, Aristóteles, Hegel e Marx priorizam, todos, um mesmo "modelo da atividade humana": a fabricação (idem, p.121). É a poiesis e não a práxis que fornece esse modelo, ao preço da redução da ação a uma atividade orientada pela categoria meios e fins, análoga àquela que produz objetos e reifica, que ergue um mundo artificial e fabrica. É assim que a filosofia política acaba se tornando uma contradição em termos, querendo a todo custo eliminar o que é próprio da política - a pluralidade, a ação e o discurso - em nome de uma segurança e de uma estabilidade que o domínio dos assuntos humanos simplesmente não é capaz de fornecer. A filosofia política é a filha bastarda da filosofia, a única - diferente da física, da metafísica, da lógica e até mesmo da ética - que a mãe não "vê com nenhuma alegria em particular" (Arendt, 1954, imagem 3); talvez porque seja a mais rebelde, aquela que, a despeito de todas as tentativas de correção, teima em não se adequar aos rígidos padrões filosóficos. Uma nova filosofia política precisa fazer da pluralidade objeto do seu espanto, o que a levaria a erigir um outro modelo de atividade humana, que não confunde a ação com a obra. Eis a primeira condição para a reconciliação da filosofia com a política. A obra filosófica de Hannah Arendt - que se apresentava como uma teórica política (e não como filósofa política) “judia, feminini generis” (Arendt, 1993, p. 170) - rompe com a "biografia do filósofo" porque quer levar a sério os assuntos humanos e recuperar a dignidade da filha bastarda. E talvez não seja um mero acidente que a pensadora que se rebela contra a filosofia ocidental reivindicando a natalidade como categoria 
central do pensamento político seja uma mulher, com diz Seyla Benhabib (Benhabib, 2000, p. 135). A pluralidade humana - "o fato de que os homens, e não o Homem, vivem na Terra e habitam o mundo" (Arendt, 2014, p. 8) - se relaciona, enquanto fato, com um outro, ainda mais elementar, de que "o novo começo inerente ao nascimento pode fazer-se sentir no mundo somente porque o recém-chegado possui a capacidade de iniciar algo novo, isto é, de agir" (idem, p. 10). A faculdade da ação é radicada ontologicamente no fato da natalidade (idem, p. 308).

$\mathrm{Na}$ segunda parte deste texto, analiso as soluções filosóficas que Arendt apresenta na sua tentativa de reconciliar a filosofia com a política no que diz respeito a dois temas centrais e interligados: a formação do juízo e da opinião. A formação dialógica e intersubjetiva de opinião (que Arendt formula com Sócrates) e o pensamento representativo (que Arendt formula com Kant) são, na minha opinião, dois dos momentos mais potentes da sua obra, capazes de nos fornecer insights preciosos para a constante atualização do seu pensamento político. Com eles Arendt responde à tradição da filosofia que de Platão a Marx tornou a ação e o discurso prescindíveis, erigindo modelos baseados na supressão da pluralidade pela ideia (antidemocrática) do "One Man”.

Vale sublinhar que Arendt se referia aos agentes como "homens" e não como "ela e ele", como as filósofas que a sucederam passaram a fazer para marcar posição de gênero. Podemos inferir que isso esconda certa insensibilidade para as questões de gênero, uma acusação frequente das teóricas feministas, da qual Arendt não se livra com muita facilidade. Mas, curiosamente, embora teime em usar "homens" um vício ainda não rompido por filósofas e filósofos nos anos 1950 -, nas primeiras páginas de $A$ Condição Humana, ela nos chama a atenção, ao introduzir justamente a noção de pluralidade, para que o relato da criação mais difundido no Ocidente se apresenta em duas versões. Em uma versão, "Deus criou o Homem (Adão)", em outra, Deus criou "macho e fêmea" (idem, p. 9). Na primeira, a mulher foi criada "do homem" e, portanto, prossegue Arendt citando Paulo, "para o homem" (idem, ibidem, nota 1). Na segunda versão, mais afeita à pluralidade humana, Ele os criou, macho e fêmea, como dito por Jesus em Mt 19,4. O que Arendt está claramente nos dizendo, nessas páginas de abertura d' $A$ Condição Humana, não é apenas que o mito segundo o qual a mulher é criada do homem a torna irremediavelmente servil ao homem ("para o homem", como diz Paulo), mas dissemina a ideia, ainda mais perversa por embasar a negação de toda a diferença, de que seríamos "repetições interminavelmente reproduzíveis do mesmo modelo" (idem, ibidem). Que o modelo seja Adão não é de se desprezar: embora Arendt não diga explicitamente que o Gênesis eleva um modelo de self masculino, ela diz explicitamente que a nossa tradição cristã trabalha com um modelo (Adão) que obsta o reconhecimento do fato da pluralidade humana. O pecado original da filosofia política é a hostilidade contra 
a pluralidade: antes e depois do cristianismo os filósofos fazem o que podem para nos reduzir ao “One Man”. Não é prerrogativa do texto bíblico, portanto. Para tornar a pluralidade humana objeto de seu espanto (thaumadzein), os filósofos "teriam antes que admitir, biblicamente falando (...) o milagre de que Deus não criou o Homem, 'mas homem e mulher' (...). Eles teriam de aceitar com mais do que simples resignação sobre a fraqueza humana o fato de que 'não é bom para o homem ficar sozinho'” (Arendt, 1954, imagem 70).

\section{Platão: a substituição da ação pela fabricação}

O antagonismo entre filosofia e política se deve fundamentalmente à oposição "entre a temporalidade, a instabilidade e a relatividade do mundo humano e a estabilidade, a permanência e a finalidade dos tópicos estritamente filosóficos" (idem, imagem 4). Platão foi o primeiro a nos alertar contra a seriedade dos assuntos humanos e, com isso, ele deu o acorde fundamental que "ressoa em infindáveis modulações através de toda a história do pensamento ocidental” (Arendt, 1992, p.44). A metáfora do acorde fundamental comunica justamente a continuidade na história dessa incapacidade do filósofo de lidar com o que é instável e relativo e que o leva a retirar-se do "mundo dos vivos" (Arendt, 2002, p. 62).

Como um acorde fundamental, a parábola da caverna narra a biografia do filósofo com uma clareza harmônica jamais repetida depois de Platão. Em três atos, a estória [story] conta a própria formação do filósofo, descrita, a cada momento, como um “ponto de inflexão" [turning point] (cf. Arendt 1954, imagens 46-7). O primeiro ato se dá dentro da caverna no momento em que o futuro filósofo se liberta dos grilhões que acorrentam as suas pernas e o seu pescoço obrigando-o a ver somente o que está à sua frente, imagens e sombras. Ao libertar-se, ele pode ver no fundo da caverna o fogo artificial que ilumina as coisas tal como realmente são. ${ }^{1}$

No segundo ato, o filósofo sai da caverna para ver o céu onde as ideias aparecem como essências verdadeiras e eternas das coisas. Este é o momento mais decisivo da biografia do filósofo: quando ele não se contenta, na sua aventura solitária, com o fogo na caverna e com as coisas aparecendo como são, “mas quer descobrir de onde vem o fogo" (idem, imagem 62). Ele se vira e encontra uma saída que o leva para o céu claro “onde não há coisas nem homens” (idem, ibidem). Iluminadas pelo sol, aparecem as ideias, "essências eternas das coisas que, na caverna, são perecíveis", e o próprio sol, a ideia das ideias (idem, ibidem).

\footnotetext{
1 "Se quisermos elaborar a história", diz Arendt, "poderíamos dizer que essa primeira periagôgé é aquela mesma do cientista que, não satisfeito com o que as pessoas dizem sobre as coisas, dá uma meia volta e quer descobrir como as coisas são por elas mesmas, a despeito das opiniões sustentadas pela multidão" (Arendt, 1954, imagem 62). O descrédito do filósofo com relação às opiniões das pessoas comuns já se anuncia aqui: não importa o que as pessoas dizem sobre as coisas.
} 
Depois do clímax, começa a tragédia. Por ser mortal, o filósofo deve voltar à caverna, que é a sua morada terrena, embora não se sinta em casa ali (cf. idem, imagem 63). Cada um desses pontos de inflexão é acompanhado pela perda de sentido e orientação: primeiro, os olhos, acostumados às sombras, são ofuscados pela luz da fogueira; depois de ajustados à luz artificial, os olhos são cegados pela luz do sol; e, por fim, devem se ajustar novamente à escuridão da caverna. Este terceiro ato é trágico porque o filósofo se encontra, nesse momento, mais desorientado do que esteve nos dois anteriores. Na cidade, o filósofo é um desorientado.

Tendo se alienado dos assuntos humanos, ele não pode mais suportar a escuridão "que considera ser caverna". Isso se dá, diz Arendt, porque o filósofo perdeu, junto com o senso de orientação, o senso comum. Quando ele volta e tenta dizer às pessoas - os cidadãos - o que viu lá fora, ele não tem e não faz sentido. Para os outros, o que o filosofo diz parece virado "de ponta cabeça”. Ele contradiz o senso comum.

Toda a alegoria é construída com metáforas que mobilizam o sentido da visão. É o filósofo quem vê as essências das coisas, ao passo que os habitantes da caverna só são capazes de ver as coisas como aparecem. Condicionados pelos seus corpos acorrentados, eles veem distorções; assim como as suas opiniões também são distorções. Enquanto o filósofo vê a verdade, os não filósofos têm uma posição no mundo, à qual corresponde e da qual depende a sua opinião: “toda doxa corresponde e depende da própria posição da pessoa no mundo” (idem, imagem 62). Não à toa o terceiro ato é o mais trágico para o filósofo, ele perdeu um lugar no mundo.

Antes de prosseguir na análise da parábola da caverna, lembro que em $A$ vida do espírito Arendt pergunta-se por que, na história da filosofia, a visão serve de metáfora para expressar o pensamento, impondo-se como a metáfora mais perene, desde Platão, para manifestar o invisível no mundo das aparências. Porque a visão é o único sentido que estabelece uma distância segura entre sujeito e objeto, distância requerida para a "objetividade" almejada pela verdade teórica. A visão é a metáfora guia da filosofia porque, desde o acorde fundamental lançado por Platão, o filósofo assume uma pretensão indevida de desvelar a verdade quando o que a faculdade de pensar pode nos proporcionar não é a verdade, mas o sentido; não é a certeza e a objetividade, mas o significado. Baseada em Kant, Arendt distingue razão (Vernuft) e intelecto (Verstand) para afirmar que o intelecto deseja apreender o que é dado aos sentidos, enquanto a razão quer compreender seu significado (Arendt, 2002, p.45). A verdade é o critério da cognição, não do pensamento:

O que recomenda a visão como metáfora-guia na filosofia - e, juntamente com ela, a intuição como ideal de verdade - é não somente a nobreza desse nosso sentido mais cognitivo, como também a própria noção inicial de que a busca filosófica pelo significado era idêntica à busca do cientista pelo conhecimento (idem, p. 92). 
A metáfora da visão utilizada pelo filósofo expressa ainda o seu desejo de aproximar-se dos deuses olímpicos que, livres das necessidades da vida mortal, podiam dedicar-se à observação do espetáculo aqui em baixo. Como os deuses, o filósofo coloca-se numa posição externa ao âmbito dos assuntos humanos (idem, p.101). No entanto, nem mesmo com isso ele se contenta: mais do que a imortalidade dos deuses - que eram imortais, mas não eternos, posto que todos tiveram, como mostra a Teogonia, um nascimento - ele almeja o Ser, que é não gerado e imperecível (idem, p. 103). O Ser torna-se a verdadeira divindade da filosofia, pois, como diz Heráclito, ele foi e sempre será “um fogo sempre vivo com medidas permanentes" (idem, ibidem). E assim, os deuses olímpicos foram derrubados pela filosofia. Usando o nous e retirando-se de todas as coisas perecíveis, engajando-se naquilo que Aristóteles chamou de theoretike energia, a mesma atividade da divindade - aquela que nos humanos é a mais elevada -, o filósofo se imortaliza (idem, p. 104). Para Platão, a imortalidade não é, como para os gregos antes da filosofia, conquistada pelos grandes e belos feitos, mas pela contemplação do eterno.

Voltando à parábola da caverna, salta aos olhos, sublinha Arendt, que Platão descreva os habitantes da caverna como se estivessem paralisados, acorrentados diante de uma tela, "sem nenhuma possibilidade de fazer qualquer coisa ou de se comunicar entre si". As duas palavras "mais significativas que designam politicamente a atividade humana, discurso e ação (lexis e práxis), estão notavelmente ausentes de toda a estória" (Arendt, 1954, imagem 63). Este é o retrato dos homens comuns, aos quais resta serem governados. Este é o retrato do homem comum feito pela filosofia política que dá início à nossa tradição. 0 acorde fundamental consiste, pois, em tornar a ação e o discurso totalmente prescindíveis: a solução para os problemas políticos, desde então, não depende da ação e tampouco do discurso. Para Platão, depende do governo.

Arendt detecta em $O$ político a versão mais sintética e fundamental "da fuga da ação para o governo" (Arendt, 2014, p. 277). Ela explica o desejo de fuga pela incapacidade do filósofo de lidar com a tripla frustração da ação: a imprevisibilidade dos resultados, a irreversibilidade do processo e o anonimato dos autores. Como resolver a dificuldade de que aquele que começa algo não permanece "senhor absoluto daquilo que começou" e termina por precisar dos outros para levar a cabo a sua intenção (que logo se vê frustrada)? O fato de as pessoas terem iniciativa, objetivos e motivações próprias instaura a instabilidade da qual o filósofo deseja se livrar. A solução encontrada por Platão é a instauração da relação entre comando e obediência, governante e governados, sendo que a diferença fundamental entre eles é que o primeiro sabe, mas não age, ao passo que os governados agem, mas não sabem (idem, 278). O governante, porque sabe, inicia (archein) o processo, os 
governados executam (prattein). ${ }^{2}$ A ação passa a ser, portanto, mera execução de ordens. Saber fazer e fazer "tornam-se dois desempenhos totalmente diferentes" (idem, ibidem). Quem sabe não precisa fazer e quem faz não precisa sequer pensar.

0 desejo desesperado do filósofo de fugir do domínio real dos assuntos humanos e a solução que ele encontra para as vicissitudes desse domínio são lidas, por Arendt, à luz de dois fatos: a morte de Sócrates e a economia baseada na escravidão. 0 julgamento e condenação de Sócrates desempenham para a história da filosofia política um papel análogo à morte de Cristo para a história da religião (Arendt, 1954, imagem 42): daí em diante, a filosofia passou a duvidar do poder da persuasão, desdenhar da ação e do discurso e instaurou uma separação radical (só contestada pra valer por Marx) entre homens de pensamento e homens de ação. Mas se o episódio da morte de Sócrates e o declínio da cidade-estado nos ajudam a compreender o desespero do filósofo (que talvez só quisesse um pouco mais de paz e segurança para viver fora da caverna), nota-se que a solução teórica encontrada por Platão tem, segundo Arendt, suas raízes na relação entre senhor e escravo. É a relação entre o senhor - que manda (porque sabe) - e o escravo - que obedece (porque não sabe) que Platão transporta para o domínio da política e transforma em seu modelo.

Degradados à condição de instrumentos, os escravos libertavam os seus senhores das atividades necessárias à manutenção da vida (Arendt, 2014, p. 151). Arendt é clara em explicitar que a escravidão era a condição prévia do exercício da cidadania e que a polis era o lugar da busca da imortalidade e da grandeza para os senhores, e apenas para eles. ${ }^{3} \mathrm{~A}$ valorização da ação em detrimento do trabalho, entre os gregos, estava diretamente relacionada à realidade da escravidão, que fornecia aos homens livres o necessário para a manutenção da vida, sem que precisassem sujar as suas mãos. A condição da cidadania era a dominação. Interessa notar que, para Arendt, não é apenas digno de nota que os filósofos tenham encontrado justificativa filosófica para a escravidão, mas que tenham, além disso, transformado a relação entre senhor e escravo, que é uma relação de dominação e degradação, em modelo da relação

\footnotetext{
2 Para a distinção instaurada por Platão entre começar ( $\operatorname{archein)~e~agir~(prattein)~e~que~transforma~a~}$ ação em execução de ordens, conferir também Arendt, 1954, imagem 14.

3 Arendt é frequentemente censurada por uma suposta "gregofilia", que se manifestaria na valorização nostálgica da cultura grega e que a teria levado a negligenciar a tremenda importância do fato de que a polis grega, mesmo nos seus áureos tempos, funcionava pela exclusão das mulheres e dos escravos do âmbito da política. O que é sensivelmente problemático nessa interpretação é a acusação de que valorizar certos aspectos da experiência da polis a teria levado a sustentar um modelo aristocrático, elitista e excludente de democracia. De fato, Arendt atribui um papel importante, em seus escritos, ao que ela chama de "cultura popular grega", tal como retratada sobretudo pela literatura grega (Arendt, 1954, imagem 8). Contudo, os elementos que ela destaca dessa cultura - a busca pela imortalidade através dos grandes feitos, a valorização da ação e do discurso e o próprio ideal de grandeza - não apagam e tampouco negligenciam o fato de que se tratava de uma sociedade baseada na escravidão, na "degradação do homem pelo homem" (idem, imagem 5). A polis não é, portanto, um modelo para Arendt. Tratei dessa questão em "Liberdade Política e Cultura democrática em Hannah Arendt" (Frateschi, 2016).
} 
entre governante e governado. Este é o sinal mais evidente do seu mais absoluto desprezo pela cidadania:

Na concepção dos gregos, a relação entre governar e ser governado, entre comando e obediência, era, por definição, idêntica à relação entre senhor e escravo e, portanto, excluía qualquer possibilidade de ação. Assim, a alegação platônica de que as normas de comportamento, nos assuntos públicos, deviam derivar da relação senhor-escravo em uma comunidade doméstica bem ordenada significa, na realidade, que a ação não deveria ter papel algum nos assuntos humanos (Arendt, 2014, p. 279, grifo meu).

A ação perde significado quando passa a ser considerada a partir das características de outra atividade humana, a fabricação. É claro que, para o filósofo (que almeja sobretudo a contemplação e com ela identifica a imortalização), a ação não tem valor nela mesma. A justificação filosófica para a falta de significado da ação é que ela é apenas um meio para um outro fim, o que instaura uma cadeia interminável, um processo sem telos, do qual o filósofo quer distância porque o seu telos é a contemplação, um fim em si mesmo. A partir do momento em que se considera a ação pela categoria meio e fim, ela passa a ser vista como fabricação (Arendt, 1954, imagem 12). Talvez em nenhum lugar isso esteja posto com mais clareza do que quando Aristóteles, diz Arendt, compara a arte de fabricar com a práxis, porque ambas teriam um fim em nome do qual são executadas. ${ }^{4}$ Isso é sem dúvida verdadeiro para a atividade da fabricação, afinal o que dá sentido a ela é o produto, mas não para a ação. Substituir a ação pela fabricação é, na verdade, o que a filosofia fez, desde a sua origem, "em busca de proteção contra as calamidades da ação”. Desde então, todas as teorias contrárias à democracia se utilizam do mesmo expediente: substituem as incertezas da ação pela segurança da fabricação (Arendt, 2014, p. 275).

A fabricação é uma atividade que envolve a imagem mental do produto e o cálculo dos meios para a produção (Arendt, 1954, imagem 13; 2014, p.281;). Quando Platão (inspirado pela experiência da escravidão) resolve os problemas da política pela instituição da relação entre governante e governados, ele transforma os governados em "fabricantes", ou seja, aqueles que colocam em prática os

\footnotetext{
4 Aristóteles ocupa um lugar mais ambíguo na história da filosofia política tal como Arendt a interpreta de Platão a Marx. Embora ela também o responsabilize pelo antagonismo entre filosofia e política, pela separação entre pensamento e ação e pela adoção do modelo da fabricação, a sua leitura de Aristóteles é mais nuançada do que esse veredicto geral nos leva a supor à primeira vista. Se Aristóteles compartilha com Platão alguns pressupostos, difere dele por entender que as duas atividades próprias da política são a ação (práxis) e o discurso (lexis) (Arendt, 2014, p. 29). 0 que distingue Aristóteles (que nisso se aproximaria de Sócrates, segundo Arendt) é que, para ele, ser um animal político "significa ter a faculdade natural do discurso" (Arendt, 1954, imagem 10), o que, para Arendt, o leva a preferir a vida na polis à realeza, à monarquia ou ao despotismo. Além do mais, Arendt se apropria da noção aristotélica de energeia para pensar a ação para além da lógica instrumental e fora da categoria meios e fins: a ação, como a virtude, é uma atividade com valor intrínseco, um fim em si mesma e não apenas meio para um outro fim (cf. Arendt, 2014, pp. 257-8).
} 
modelos e padrões estabelecidos pelo governante (que, no caso de Platão, seria melhor coincidir com o filósofo). E mesmo que em certos momentos ele conceda aos cidadãos alguma participação na condução dos assuntos públicos, “todos 'agiriam', na verdade, como um só homem, inclusive sem ter a possibilidade de dissensão interna e muito menos de luta de caráter partidário: por meio do governo, 'os muitos se tornam um, em todos os aspectos', exceto na aparência corporal” (Arendt, 2014, p. 279, grifo meu). Em suma, a substituição da ação pelo governo corresponde à redução da ação à fabricação. E não apenas os governados “fabricam”, o rei filósofo, na República, também "aplica as ideias como o artesão aplica suas regras e padrões; ele 'faz' a sua cidade como o escultor faz uma estátua” (idem, 283). Este modelo - que identifica conhecimento com comando e ação com obediência e execução tornou-se peremptório para a tradição do pensamento político (idem, p. 280). E é precisamente com ele que a nova filosofia política precisa romper se quiser abarcar a pluralidade humana e resguardar o lugar central da ação.

O desejo de Platão de substituir a ação pela fabricação para "conferir ao domínio dos assuntos humanos a solidez inerente à obra e à fabricação” termina por conferir à doutrina das ideias uma função política. Na República, as ideias se convertem em padrões de comportamento com o fim exclusivo de "eliminar dos assuntos humanos seu caráter de fragilidade" (idem, p. 282). Para o filósofo, a ideia mais elevada, convém lembrar, é o belo, mas, para o rei-filósofo, a ideia mais elevada é o bem, pois o permite governar os homens entre os quais terá que passar a sua vida, visto "não poder habitar para sempre sob o céu das ideias" (idem, ibidem):

Somente quando volta à caverna escura dos assuntos humanos, para conviver novamente com os seus semelhantes, é que ele [o filósofo] necessita das ideias orientadoras como padrões e regras pelas quais medir e sob as quais subsumir a variada multiplicidade de palavras e atos humanos, com a mesma certeza absoluta $e$ "objetiva" com que o artesão pode se orientar na fabricação e o leigo no julgamento de camas individuais ao usar o modelo estável e sempre presente, a "ideia" da cama em geral (idem, ibidem, grifo meu).

\section{Hegel e Marx: a fuga moderna da política para a história}

Ao afirmar que "os filósofos apenas interpretaram o mundo de diferentes maneiras, agora é preciso transformá-lo”, Marx se rebela contra a tradição filosófica porque, embora os filósofos tenham se disposto a prescrever as regras da ação para colocar ordem no hospício, nenhum deles jamais elegeu a transformação do mundo como a sua principal preocupação: “Essencialmente, de Platão a Hegel, a filosofia 'não era desse mundo'” (Arendt, 1992, p.50). A rebelião de Marx reside 
na predição de que o mundo dos negócios humanos comuns, onde nos orientamos e pensamos em termos de senso comum, se tornará um dia idêntico ao domínio das ideias em que o filósofo se move, ou de que a filosofia, que "sempre foi para os poucos" se tornará um dia a realidade do senso comum para todos (idem, pp.50-1, tradução modificada).

Assim, para Arendt, a quebra da tradição operada por Marx consiste precisamente na negação de que a verdade (e a filosofia) esteja localizada fora dos assuntos dos homens e do mundo comum e na aposta de que ela possa ser realizada na esfera do convívio, na sociedade (idem, p. 44):

Ao reinterpretar a tradição do pensamento político e levá-la ao seu fim, é crucial que Marx conteste não a filosofia, mas a sua alegada impraticabilidade. Ele contesta a resignação dos filósofos que não fazem mais do que buscar um lugar para si mesmos no mundo, ao invés de tentar mudá-lo e torná-lo, por assim dizer, filosófico. $E$ isso não apenas vai além, mas também é decisivamente diferente do ideal platônico de filósofos que governam como reis, porque implica não o governo da filosofia sobre os homens, mas que todos os homens possam, por assim dizer, tornar-se filósofos (Arendt, 2008, p. 143, grifo meu). ${ }^{5}$

Trata-se de um rompimento muito significativo com a filosofia política tradicional a afirmação de que a filosofia deve transformar o mundo tendo-o interpretado: isso significa que a transformação é precedida de interpretação, “de modo que a interpretação do mundo pelos filósofos indique o modo como ele deveria ser transformado" (Arendt, 1992 , p. 50). Platão e Hegel jamais consideraram que a sua tarefa seria a de interpretar o mundo para transformá-lo, contentaram-se em prescrever regras de ação. Marx se rebela conscientemente contra isso. Contudo, a sua rebelião contra a tradição findou em autoderrota (idem, p. 58). Se a tradição da filosofia política começou quando Platão descobriu que é inerente à experiência filosófica repelir o mundo dos negócios humanos, ela termina com Marx privando "o pensamento de realidade e a ação de sentido" (idem, p. 52). Apesar do seu enorme esforço - digno de reconhecimento - para suplantar a tradição, Marx não apenas não recupera o significado da ação, como também priva o pensamento da realidade. Vejamos.

Arendt vê uma continuidade no pensamento de Marx, da juventude à obra madura. O jovem Marx não é visto por ela como mais democrático e naquilo que a interessa - que é o papel que ele atribui à política e à pluralidade - ele manteria uma coerência inegável do começo ao fim, infelizmente. As proposições chave da sua filosofia política, "que subjazem e transcendem a parte estritamente científica da sua obra", permanecem as mesmas durante toda a sua vida, dos primeiros escritos

\footnotetext{
5 Arendt continua: "A consequência que Marx extraiu da filosofia da história de Hegel (e toda a obra filosófica de Hegel, incluindo a 'Lógica', tem um único tema - a história) é que a ação, ou práxis, contrariamente a toda a tradição, estava tão distante de ser o posto do pensamento, que era o autêntico e verdadeiro veículo do pensamento, e que a política, longe de estar infinitamente abaixo da dignidade da filosofia, era a única atividade intrinsecamente filosófica" (Arendt, 2008, p. 143).
} 
até o último volume d' O capital (Arendt, 1992, p. 48). O veredito de Arendt é que não adianta procurarmos um Marx mais democrático nos textos de juventude. Mas isso não é razão suficiente para recusarmos a sua grandeza enquanto filósofo.

Agrandeza de Marx repousa (assim como a de Kierkegaard e Nietzsche) no fato de ter percebido "o seu mundo como um mundo invadido por problemas e perplexidades novas com as quais a nossa tradição de pensamento político não era capaz de lidar" (idem, p. 54). Ao constatar que a tradição silenciava diante dos problemas que o seu próprio tempo impunha, Marx entendeu ser necessário radicalizar contra ela, não bastaria simplesmente reconsiderar o passado ou fazer certos ajustes teóricos (idem, p. 55). A teoria de Marx é indicativa, portanto, de um passado que perdeu a sua autoridade no presente e, por causa dele, estamos em uma posição melhor agora, pois temos a "oportunidade de olhar sobre o passado com olhos desobstruídos de toda tradição, com uma visada direta que desapareceu do ler e do ouvir ocidentais desde que a civilização romana submeteu-se à autoridade do pensamento grego" (idem, p. 56). Em outras palavras, para Arendt, Marx estava genuinamente envolvido com o problema - que também se impõe aos teóricos do século XX, depois das grandes guerras - de enfrentar fenômenos novos dentro do quadro conceitual da tradição. Ele estava perfeitamente ciente da incompatibilidade entre o pensamento político clássico - que considerava o trabalho humano a mais desprezível das atividades - e a elevação do trabalho à sua máxima produtividade, tal como ocorreu depois da Revolução Industrial. ${ }^{6}$ Ou seja, havia uma clara incompatibilidade entre os conceitos tradicionais, que faziam do trabalho símbolo da sujeição do homem à necessidade, e a época moderna, que passou a ver o trabalho como símbolo da liberdade positiva, a liberdade da produtividade (idem, p. 60). Marx entendeu que, para resolver essa dificuldade, era preciso salvar o pensamento filosófico (considerado pela tradição a mais livre das atividades humanas) do impacto do trabalho considerado como atividade voltada meramente à supressão da necessidade. Marx entendeu que a filosofia tradicional tinha um conceito de trabalho que não se adequava mais à sua valorização moderna. ${ }^{7}$ Assim, contra as abstrações da filosofia e seu conceito de

6É nesse contexto que se passa a afirmar "o ideal de liberdade sob condições inauditas de igualdade universal" (Arendt, 1992, p. 59), mas Marx também sabia que a questão da igualdade era colocada apenas superficialmente nas "teorias idealistas" a respeito da igualdade do homem e da sua dignidade inata e sabia ainda que a resposta não estaria dada apenas pela concessão do direito de voto aos trabalhadores. Não se tratava, para ele, de um problema de justiça que pudesse ser resolvido concedendo à nova classe de trabalhadores o que the era de direito (idem, p. 60) como se disso se seguiria a restauração automática da antiga ordem suum cuique [dar a cada um o que é seu]. Arendt está plenamente de acordo com Marx nesse aspecto: a afirmação burguesa da igualdade universal e a mera concessão do direito de voto aos trabalhadores esconde o problema, não o resolve (o que ela discorda é do modo pelo qual Marx pretende resolver o problema).

7 Mas quando ele afirmou que não se poderia "abolir a filosofia sem realizá-la" passou a sujeitar o pensamento ao inexorável despotismo da necessidade, submetendo-o às "leis férreas" das forças produtivas da necessidade (Arendt, 1992, p. 60). Essa é uma das razões pelas quais, segundo Arendt, a rebelião de Marx contra a tradição findou em autoderrota. 
homem como animal rationale, ele afirmou que a humanidade do homem consiste em sua força produtiva, a sua força de trabalho, definindo-o como animal laborans.

Marx não foi simplesmente um materialista que trouxe o idealismo de Hegel para a terra, esclarece Arendt. Para Hegel, o movimento dialético do pensamento é idêntico ao movimento dialético da própria matéria e mediante a introdução do espírito ele acreditava ter demonstrado uma identidade ontológica entre matéria e ideia. Portanto, não tem importância que se inicie o movimento do ponto de vista da consciência ou tendo como ponto de partida a matéria. 0 fato de Marx aceitar o conceito de "movimento dialético" concebido por Hegel como lei universal torna os termos "idealismo" e "materialismo" sistemas filosóficos sem significado (idem, p. 67). Ele era ciente, portanto, de que a sua oposição a Hegel e seu repúdio da tradição não repousava em seu "materialismo", mas em sua recusa em admitir que a diferença entre a vida do homem e a vida animal seja a ratio, ou o pensamento. 0 homem é essencialmente um ser natural dotado da faculdade de ação e a ação permanece natural porque consiste em trabalhar (metabolismo do homem com a natureza). Então, a sua reviravolta vai ao cerne do problema, que não é a substituição do idealismo pelo materialismo, mas a questão da qualidade especificamente humana, que passa a ser identificada com o trabalho.

Acontece que Marx termina por colocar Platão e Hegel novamente de "cabeça para cima" e permanece preso a Hegel mais do que parece à primeira vista (idem, p. 63). Hegel é o responsável pela transformação da metafísica tradicional em filosofia da história e o ponto central é que a filosofia política de Marx "não se baseava sobre uma análise dos homens em ação, mas, ao contrário, na preocupação hegeliana com a História" (Arendt, 1992, p. 112). Foi o Marx historiador, não o Marx filósofo, quem se politizou.

Com Hegel a história conquistou a dignidade suprema de revelar a verdade absoluta e uma vez que essa qualidade reveladora não era inerente a nenhum evento singular, mas sim ao processo histórico como um todo, "a própria história se torna o tópico autêntico da filosofia” (Arendt, 1954, imagem 30). O que interessa sobretudo a Arendt a respeito de Hegel é que

(...) na corrente gigantesca que, com o começo da humanidade civilizada, começou a revelar a verdade absoluta do Espírito em um desenvolvimento sobre-humano, os nítidos contornos dos eventos e ações são tão dissolvidos quanto a singularidade de quaisquer pensamentos particulares. Se o significado, de acordo com o passado préplatônico dos gregos, se manifestava na ação quando e se ele se manifestava pelo discurso; se o significado, no desenvolvimento filosófico específico do Ocidente, foi então revelado como verdade contemplada, então o significado em Hegel não adere nem à ação nem ao pensamento como tal, mas apenas ao desenvolvimento histórico que submerge ambos (idem, ibidem).

O papel do filósofo, então, está garantido, afinal o processo histórico se revela para ele, com a sua "mente voltada para compreender o passado". Mas a que preço! 
Ao preço de que o significado só se revela para ele quando a estória [story] chega ao fim, de que a percepção da verdade vem quando tudo acaba e como consolação por ter vindo tão tarde. Do ponto de vista do agente, entretanto, a vida ativa é sem significado, pois é o "ardil da razão" que o direciona. Por isso Hegel pode ver a história como a história da raça humana considerada como um indivíduo, construída "como se fosse a biografia deste indivíduo monstruoso e gigantesco - a humanidade" (idem, imagem 31). Se o fim último da filosofia é reconciliar pensamento e realidade e se a filosofia é verdadeira teodiceia, o preço dessa reconciliação é a obliteração da pluralidade humana e também "da variedade, da imprevisibilidade e das contradições de suas ações" (idem, ibidem).

A imagem da história é construída como um Sujeito gigante - "um Homem artificial" - cujo significado é o produto final da atividade da humanidade. Qualquer coisa que uma pessoa diga ou pense é apenas uma parcela do produto final da história. Para Arendt, Hegel faz com a multiplicidade das ações e eventos o mesmo que Platão fez com as opiniões: os mede com o metro do Absoluto, "assim como Platão mediu as opiniões como o metro da verdade" (idem, imagem 41). Nos dois casos, o múltiplo é sacrificado ao Um e a "pluralidade dos homens, que se expressa politicamente em opiniões”, é eliminada:

Assim como Platão exigia que Um Homem, o rei-filósofo que sabia a verdade, deveria governar os muitos, também Hegel exigiu que um filósofo, para cujo olhar retrospectivo o Absoluto se revela no processo do tempo, devia ser o possuidor e atribuidor do significado pelo qual todos os outros homens em seus feitos e pensamentos lutam em vão (idem, ibidem).

Também como para Platão, o significado e o telos da ação não está nela mesma: a ação é avaliada pelo mesmo critério que avaliamos a fabricação. Mais ainda: a própria história passa a ser vista como um "processo gigantesco de fabricação" no qual um sujeito singular fabrica o produto final que apenas o filósofo será capaz de perceber adequadamente. Subjaz à afirmação de Hegel de que o real é racional a mesma hostilidade original do filósofo contra a política que Platão expressa na sua alegoria da caverna. E a própria ideia de reconciliação com a realidade fala claramente a linguagem platônica: o filósofo se reconcilia com o domínio dos assuntos humanos porque (só ele) consegue perceber ali o Absoluto. Sem o filósofo, esse domínio inevitavelmente recairia num vazio de significado (idem, imagem 38):

\footnotetext{
A história - baseada na suposição manifesta de que não importa quão acidentais as ações isoladas possam parecer no presente e em sua singularidade, elas conduzem inevitavelmente a uma sequência de eventos que formam uma estória [story] que pode ser expressa através de uma narrativa inteligível no momento em que os eventos se distanciarem no passado - tornou-se a grande dimensão na qual os homens se "reconciliam" com a realidade (Hegel), a realidade dos assuntos humanos, isto é, das coisas que devem sua existência exclusivamente aos homens (Arendt, 1992, p. 121, tradução modificada).
} 
A "narrativa inteligível” salva as ações singulares da sua acidentalidade e carência de sentido. Veremos adiante que, para recobrar a dignidade e o sentido do singular, Arendt deverá ressignificar a ideia hegeliana de reconciliação com a realidade. Mas, para tanto, será necessário recusar a identificação tradicional, assimilada por Hegel, da fabricação como modelo da atividade humana. Se Marx pretendeu romper com a tradição, a sua rebeldia não foi a ponto de abandonar o modelo de fabricação: para ele, a ação é a mesma coisa que "fazer a história" (idem, p. 112).

Com Hegel, a filosofia se torna interpretação da história. Marx, por sua vez, transforma a história em ciência. Para tanto, bastou a ele trocar a palavra "Espírito" - o sujeito oculto do processo de fabricação de Hegel - pela palavra "Sociedade" - o sujeito do processo histórico (Arendt, 1954, imagem 33). Assim como Hegel mostrou que a verdade do passado é realizada na lembrança do passado como um todo, também Marx "desenha um futuro no qual a verdade será realizada na Sociedade como um todo" (idem, ibidem). Com ambos a história passa a desempenhar, nos tempos modernos, o papel da política, ao mesmo tempo em que esta é degradada a uma "mera técnica de administração, manipulação e representação" (idem, imagem 37). "Fazer a história" toma o lugar da ação política na medida em que a ação é vista em termos de fabricação (making) e a história se torna realidade definitiva. Novamente, o modelo da fabricação mina o significado da vida humana em conjunto, da vida política.

Ao tornar o homem de ação o criador consciente do futuro, o "fabricante da história", Marx leva às últimas consequências a identificação tradicional da ação com fabricação: na medida em que a fabricação sempre envolve um elemento de violência, Marx vê a ação como essencialmente violenta. A tese de que a violência é a parteira da História tem aqui a sua raiz mais profunda, na identificação da ação e da história com a fabricação. A partir daí (eis o perigo extremo) o fim passa a justificar todos os meios, inclusive os mais terríveis que pode haver no campo da política (idem, imagem 34). Se pensamos nesses termos, não haverá nada que não possa ser justificado ou não pareça plausível em determinado momento.

O ponto essencial, para Arendt, é que a filosofia política de Marx não se baseia em uma análise dos homens em ação e sim na preocupação hegeliana com a história: ele completa e aperfeiçoa a tradicional identificação da ação com o fazer e o fabricar ao tornar o historiador portador de um modelo que guia o artesão. 0 perigo não está propriamente em tornar imanente o transcendente, mas sim em transformar “desígnios superiores desconhecidos e incognoscíveis em intenções planejadas e voluntárias" de modo que o sentido passa a ser identificado com o fim. Isso acontece quando Marx toma o significado hegeliano de História - "o progressivo desdobramento e realização da ideia de liberdade - como sendo fim da ação humana” (Arendt, 1992 
p. 113). A liberdade passa, assim, a ser o fim último e o "produto final” de um processo de fabricação.

A teoria das superestruturas ideológicas, embora pareça introduzir uma novidade extraordinária no pensamento político, carrega o mesmo preconceito contra o discurso nutrido por Platão. A teoria das superestruturas - os campos da atividade humana nos quais os homens se expressam através do discurso (religião, legislação, arte ou filosofia) - sustenta que a função do discurso não é revelar a verdade, mas ocultá-la (Arendt, 1954, imagem 35). Marx a complementa com a "fórmula" da luta de classes, que desvendaria todos os segredos da história, assim como "a lei da gravidade parecia desvendar todos os segredos da natureza” (Arendt, 1992, p. 115). Arendt admite que essa fórmula apresenta um padrão baseado em um importante discernimento histórico. Contudo, ela abre caminho para que se passe a pensar a história através de padrões, o que resulta na ruína do factual e do particular de tal modo que a estrutura factual básica do processo histórico e a própria cronologia correm o sério risco de ser solapados. O problema de pensar a história dessa maneira é que, no limite, qualquer padrão que apraza se torna capaz de explicar fatos passados (idem, p. 116).

Em suma, Marx faz um salto da teoria para a ação e da contemplação para o trabalho depois de Hegel ter transformado a metafísica tradicional em uma filosofia da história "e transformado o filósofo no historiador a cuja visada retrospectiva o significado do devir e do movimento - não do ser e da verdade - revelar-se-ia afinal" (Arendt, 1992 , pp. 56-7). No entanto, ao saltar da filosofia para a política, Marx

(...) transportou as teorias da dialética para a ação, tornando a ação política mais teórica e mais dependente do que nunca daquilo que hoje chamaríamos de ideologia. Além do mais, uma vez que o seu trampolim era, não a metafísica antiga, mas a filosofia da história de Hegel (...) ele superpôs "a lei da História” à Política, findando por perder o significado de ambas - da ação não menos do que do pensamento, e da Política não menos que da filosofia - ao insistir que eram meras funções da sociedade e da história (idem, p. 57).

Marx termina, enfim, por resolver a experiência do novo "em algo velho" (idem, p. 56). Cumpre notar que não é apenas a ação que perde significado, mas também o pensamento, e essa dupla perda é, para Arendt, o sinal mais claro de que a rebelião de Marx findou em autoderrota.

Com três teses Marx desafiou verdades tidas por incontestes até a época moderna. Com a tese segundo a qual o trabalho criou o homem, ele desafia o Deus tradicional, ao mesmo tempo em que afirma que a humanidade do homem, agora caracterizado como animal laborans e não mais como animal racional, é resultado de sua própria atividade: se razão era o atributo mais elevado do homem e o trabalho, o mais desprezado, Marx dá uma dignidade ao trabalho jamais aceita pela tradição, como vimos a partir de Platão e Aristóteles. Com a tese de que a violência é parteira 
da História e que é unicamente em períodos violentos que a História mostra a sua face autêntica para deixar de ser ideologia, Marx glorifica a violência ao mesmo tempo em que nega a definição aristotélica do homem como ser dotado de logos e capaz de discurso, aquelas mesmas características que, para Aristóteles, diferenciavam os homens livres - que conduziam os assuntos humanos pelo discurso e pela persuasão dos bárbaros - governados pela violência (e dos escravos, claro). Por fim, a afirmação de que os filósofos interpretaram o mundo, agora é preciso transformá-lo, ele afronta todo o pensamento ocidental, de Platão a Hegel, para os quais a filosofia não é desse mundo.

Contudo, as três teses contêm contradições fundamentais e conduzem Marx a dificuldades profundas. (1) Se o trabalho define o homem, que atividade humana restará quando os homens dele se emanciparem após a revolução? Que atividade essencialmente humana restará? Marx faz do homem animal laborans ao mesmo tempo em que almeja para ele uma sociedade "na qual essa força, a maior e mais humana de todas, já não é necessária” (Arendt, 2014, p. 129). Eis a sua contradição fundamental. (2) Se a ação violenta é a mais digna das ações e é a parteira da História, como serão os homens capazes de agir de modo significativo depois da conclusão da luta de classes?.. (3) Quando a filosofia tiver sido realizada e abolida, que espécie de pensamento restará? (Arendt, 1992, p. 51).

Arendt reconhece que contradições fundamentais raramente ocorrem em autores de segunda ordem e Marx não é, para ela, um autor de segunda ordem. Elas ocorrem quando temos que lidar com fenômenos novos em termos de uma tradição de pensamento velha, "fora de cujo quadro conceitual pensamento algum parecia possível” (idem, p. 52). Marx tenta desesperadamente pensar contra a tradição utilizando as suas próprias ferramentas conceituais, mas não consegue completar a tarefa. O problema central e que termina por amarrá-lo à tradição que ele pretendia superar é a glorificação do trabalho (labor) e a atribuição ao trabalho de características que são próprias de uma outra atividade, a fabricação (work) de objetos para um mundo durável. Do mesmo modo, a glorificação da violência e a projeção de uma sociedade harmonizada significam, ao fim e ao cabo, a desvalorização da ação e do domínio público. A definição do homem como animal laborans opera um duplo reducionismo que redunda, finalmente, na abolição da própria política. Em primeiro lugar, Marx define o homem como um animal que trabalha, definição que confina o homem à sua capacidade produtiva (que, na verdade, não é senão aquela que satisfaz as suas necessidades); tendo feito isso, ele substitui a multiplicidade de interesses e perspectivas individuais por interesses de grupo ou de classes que são,

8 Para Arendt, a teoria das superestruturas ideológicas "assenta-se, em última instância, em sua hostilidade antitradicional ao discurso e na concomitante glorificação da violência" (Arendt, 1992a, p. 50). 
por sua vez, reduzidas a apenas duas: a dos capitalistas e a dos trabalhadores (cf. Arendt, 2014, p. 51). 0 indivíduo perde, com isso, a possibilidade de reivindicar qualquer identidade ou ponto de vista que não seja a identidade ou ponto de vista supostamente adequados à classe à qual pertence. Ocorre que a diluição do indivíduo na classe ou na sociedade socializada pós-revolução sustenta a ficção de uma harmonia que não pode comportar a construção de um mundo comum compartilhado entre indivíduos e grupos distintos, que vejam o mundo de perspectivas distintas e que tenham demandas e vontades conflitantes. Marx sacrifica, enfim, a pluralidade humana.

\section{Hannah Arendt: opinião e juízo}

$\mathrm{Na}$ estória que Hannah Arendt conta sobre si mesma, o seu interesse pelas questões políticas surgiu quando "alguém bateu com um martelo em minha cabeça e, podemos dizer, isto me despertou para a realidade" (Hill, 1979, p. 319). O martelo é uma metáfora para o nazismo e comunica que o despertar foi violento. Mas mesmo depois de ter escrito As origens do totalitarismo (1951), A condição humana (1958), Entre o passado e o futuro (1961) e Sobre a revolução (1963) ela rejeitava ser identificada como filósofa e preferia o título de "teórica política". A sua briga com a filosofia política ocidental é longa, vai da juventude até a idade madura, e é travada com a certeza de que os filósofos, em geral, são hostis com a política e com a pluralidade, o que os torna incapazes de lidar com as particularidades, fragilidades e incertezas dos assuntos humanos. Arendt não se reconhecia entre eles. Além do mais, ela tinha uma dúvida genuína a respeito da possibilidade de conciliar a filosofia com a política, ou seja, "a temporalidade, a instabilidade e a relatividade do mundo humano e a estabilidade, a permanência e a finalidade dos tópicos filosóficos" (Arendt, 1954, imagem 4). No entanto, embora hesitante quanto à possibilidade de resolver o antagonismo entre a filosofia política, Arendt buscou, ao longo de toda a sua obra, maneiras de superá-lo.

Em “Philosophy and Politics” (1954), Arendt encontra em Sócrates uma resposta para a oposição entre filosofia e política inaugurada por Platão e que aprofunda a cisão entre verdade e opinião. A alegoria da caverna instaura essa cisão e é por causa dela que a filosofia perde relevância para a polis. Traumatizado pela condenação do mestre, Platão abandona a expectativa de tornar a filosofia relevante para a cidade e parece se contentar em encontrar um modo de salvar a pele dos filósofos: o modo que encontrou de fazer isso foi colocar o filósofo - o portador da verdade - para governar os ignorantes - escravizados às suas opiniões. Foi assim que Platão abriu, na história do pensamento ocidental, o antagonismo entre a filosofia e a política. 
Desde o manuscrito de 1954, ela se mostra comprometida com a recuperação da dignidade da opinião. Entendo que este é um dos aspectos mais relevantes da sua obra e também dos mais promissores para aquilo que ela se propõe: pensar a possibilidade de reconciliar a filosofia com a política. Vejamos.

De acordo com Arendt, para Sócrates, a opinião é a "formulação em discurso do que aparece para mim". Ela expressa o "mundo tal como se abre para mim" (idem, imagem 48). A interpretação que ela faz de Sócrates, cumpre sublinhar de antemão, traduz o pensamento socrático de acordo com as suas próprias pretensões: Sócrates dá a Arendt um caminho filosófico para desfazer o abismo que Platão teria aberto. Para o Sócrates da Arendt, a opinião é a formulação em discurso do mundo tal como aparece para mim de modo que ela se forma apenas se eu tenho um lugar nesse mundo de aparências, que é o espaço público. Manifestar uma opinião é comunicar aos outros como eu vejo o mundo deste lugar que estou. Deve-se notar que ela encontra em Sócrates algo análogo ao que encontrará em Kant (no pensamento representativo) posteriormente: se a opinião, para Sócrates, não pode ser "algo absoluto e válido para todos", tampouco é "fantasia subjetiva e arbitrariedade" (idem, ibidem). A opinião pode ser depurada, assim como a virtude pode ser de algum modo ensinada. Não fosse, a maiêutica não poderia apostar no processo dialógico que visa ajudar as pessoas a encontrarem "a verdade na opinião". Se queremos permanecer fiéis à metáfora da maiêutica, diz Arendt, devemos entender que "Sócrates queria tornar a cidade mais verdadeira ao assistir cada um dos cidadãos a parir suas próprias verdades" (idem, imagem 49). 0 método é a dialética, mas a dialética socrática não destrói a doxa, "ao contrário, revela essa doxa em sua própria veracidade". 0 papel do filósofo não é, portanto, o de dizer a verdade filosófica às pessoas comuns, mas "tornar os cidadãos mais verdadeiros" (idem, ibidem).

Interessa a Arendt, sobretudo, que a opinião não seja vista como mera fantasia subjetiva e tampouco como verdade válida para todos. Isso também vale para o juízo que, como veremos a seguir, não se forma pela subsunção do particular a uma regra universal, mas nem por isso é expressão de pura idiossincrasia. Arendt vai nos indicando, desde pelo menos o manuscrito de 1954, que a formulação de uma nova filosofia política precisa operar nesse intervalo, entre a mais estrita subjetividade e a certeza de um a priori que o mundo dos assuntos humanos jamais terá.

Também interessa particularmente a Arendt detectar em Sócrates e na sua maiêutica uma postura filosófica que afirma que "ninguém pode saber por si mesmo e sem maiores esforços a verdade inerente de suas opiniões" (idem, ibidem). Quando Platão descreve os homens da caverna como estáticos e mudos, desconsidera que a opinião se forma em diálogo, com os outros, no espaço público. A dialética de Sócrates era uma atividade política, "um dar e receber", baseada na igualdade, e cujos frutos "não poderiam ser medidos por resultados, por ter chegado a esta ou 
aquela verdade”. Que o diálogo fosse inconclusivo não era, portanto, um problema (como não era nos escritos mais socráticos de Platão): “ter discutido algo, ter falado sobre algo (...) parecia resultado em si suficiente” (idem, imagem 51). Enquanto atividade política, o diálogo é por si mesmo valioso.

O diálogo não requer conclusão ou consenso para ser significativo. Aos falarmos sobre as coisas, elas se tornam comuns, são compartilhadas e disso surge a "qualidade comum [commonness] do mundo político". Isso não significa, evidentemente, pressupor que todos sustentem as mesmas opiniões e compartilhem o mesmo ponto de vista. Muito pelo contrário, o mundo se abre de diferentes maneiras para as pessoas, que ocupam lugares distintos e olham o mundo de perspectivas diferentes. $O$ desafio é que encontrem um modo de viver juntos sem que para isso precisem se tornar um só Homem.

Se a philia aristotélica tem algo de inspirador para Arendt é porque não pressupõe equalização: os amigos não se tornam iguais, mas sim "parceiros iguais no mundo comum", eles “constituem juntos uma comunidade” (idem, ibidem). Interessa particularmente a ela que para Aristóteles seja a amizade, e não propriamente a justiça (ou não apenas a justiça), que mantém a comunidade. Ou, em outros termos, a amizade cívica seria melhor para esse propósito do que a justiça porque esta, embora seja imprescindível por estabelecer os muros que nos separam, não nos torna parceiros no mundo comum.

0 que Arendt extrai de Sócrates, combinando-o com Aristóteles, é que a dialética força o falante a manifestar a verdade da sua opinião de modo que o outro possa entender "como e com qual articulação específica o mundo comum aparece" para ele. O outro é, diz Arendt, "para sempre desigual e diferente" (idem, ibidem). Eu compreendo a sua diferença na medida em que ele a expressa discursivamente para mim. Ver o mundo do ponto de vista do outro é "a percepção (insight) política por excelência" (idem, ibidem).

Arendt interpreta o "Conheça a ti mesmo" como querendo dizer que é apenas conhecendo o que aparece para mim e permanecendo em relação com a minha existência concreta que eu posso compreender a "verdade", a minha e a do outro. A verdade absoluta - ou seja, a verdade que seria a mesma para todos e independente da existência de cada um e do lugar que ocupa - não existe para os mortais. Os filósofos precisam lidar com isso e precisam compreender o que isso significa para os mortais, entre os quais se inclui. Para estes "o importante é tornar a doxa verdadeira, enxergar em cada doxa a verdade e falar de tal maneira que a verdade da opinião das pessoas se revele para elas mesmas e para os outros" (idem, imagem 53). Quando Sócrates diz "que sabe que nada sabe", ele está querendo dizer que sabe que não possui a verdade válida para todo mundo e que não pode saber a verdade do outro senão “perguntando para ele” (idem, ibidem). 
Ela imputa a Sócrates o que gostaria que fosse a postura do filósofo diante dos assuntos humanos. A nova filosofia política - que faria da pluralidade objeto do seu espanto - tem que começar por aceitar, como Sócrates fez, os limites da verdade para os mortais. Isso não faz dele um sofista, afinal não se trata de ceder à arbitrariedade e à ilusão subjetiva. Recusar a verdade absoluta não leva necessariamente à arbitrariedade e tampouco encerra os indivíduos neles mesmos. Há um critério operando aqui: para falar verdadeiramente de sua própria doxa, é preciso que a pessoa esteja em acordo consigo mesma, ou seja, que não contradiga a si mesma e não diga coisas contraditórias (idem, imagem 54). Isso exige, em primeiro lugar, um diálogo interno, pois somos dois-em-um e quando pensamos dialogamos com o outro que também somos. Arendt faz uma analogia entre o outro que há em mim e o amigo, definido por Aristóteles como o "other self”, para defender que somente aquele que tem a experiência de falar consigo mesmo - e estar em acordo ou descordo consigo mesmo - é capaz de se tornar amigo, "de adquirir um other self" (idem, ibidem). A faculdade do discurso e o fato da pluralidade humana se relacionam na medida em que falando comigo mesma (com a outra que há em mim) eu vivo junto comigo mesma; e na medida em que falo com os outros eu posso viver junto com eles. É apenas na companhia dos outros, que me chamam de volta do diálogo interno do pensamento, que eu posso me tornar um self, "um ser humano único e singular falando com uma voz e reconhecido como tal pelos outros" (idem, imagem 55). Em outras palavras, é do reconhecimento da minha singularidade pelos outros, tal como eu a expresso pela minha voz, que depende a minha identidade, para mim mesma e para os outros.

A tese socrática de que a virtude pode ser ensinada é, pois, uma aposta em que o exercício do diálogo (e do pensamento, o diálogo interno) que busca a não contradição e envolve escuta pode vir a "melhorar homens e cidadãos" (idem, imagem 56). Por isso, o principal objetivo político de Sócrates era ensinar os atenienses a pensarem por si mesmos, de maneira independente e sem o auxílio de quaisquer doutrinas. Aí residiria a relevância política da filosofia, não em desvelar a verdade absoluta.

A consequência mais importante da identificação que Platão e Aristóteles fazem da vida mais elevada com a contemplação é a separação radical entre pensamento e ação. Essa separação entre pensamento e ação, entre bios theoreticos e bios politikos ou entre vida contemplativa e vida ativa corre como um "fio condutor ao longo de toda a história da filosofia política" (idem, imagem 6). ${ }^{9}$ Não que Sócrates

9 Em Entre o passado e o futuro, ela coloca nos seguintes termos: nem Platão nem Aristóteles acreditaram em momento algum que os homens pudessem imortalizar-se através de grandes feitos (deeds) e palavras (words). Descobriram na atividade do pensamento a capacidade humana para libertar-se da esfera dos assuntos humanos, que não deveriam ser levados a sério em demasia. Imortalizar passa a significar, para os filósofos, habitar com as coisas que existem para sempre, 
os considerasse idênticos, mas como intimamente relacionados, de modo que o próprio pensamento é um tipo de ação e a significação da ação se relaciona com o fato dela desvelar de algum modo o pensamento. 0 que melhora as pessoas é a conscientização de que são seres de pensamento e de ação, "cujos pensamentos invariavelmente e inevitavelmente acompanham as suas ações”. É a consciência desse fato, diz Arendt, que "melhora os homens e cidadãos" (idem, imagem 56). 0 discurso desempenha papel central nessa relação entre pensamento e ação porque é nele (enquanto faculdade humana) que ambos estão fundamentados. A ação sem discurso é desprovida de significado, assim como todo pensamento, enquanto manifestação ativa, se funda no discurso ${ }^{10}$.

Ao contrário de Sócrates, Platão aposta que a solução para a vida política passa pela instituição de um corpo político fundado na relação de mando e subordinação, um organismo no qual os homens vivem como se fossem Um homem ["One man"] (idem, imagem 68). Se o filósofo está capacitado para governar os outros é porque ele resolve nele mesmo a contradição entre corpo e alma. Porque sua alma governa (tiranicamente) o seu corpo, ele seria melhor para governar os demais, que não são capazes de governar a si mesmos (idem, imagem 61). Na verdade, para Arendt, o filósofo mata a pluralidade nele mesmo e, claro, não poderia fazer diferente quando chamado a resolver os problemas da cidade. O governo tirânico de si mesmo é replicado na política (idem, imagem 68 ).

Que o filósofo destrói a "pluralidade da condição humana dentro de si mesmo" (idem, ibidem) não é uma tese secundária e talvez seja a razão mais profunda pela qual Arendt se proponha, no manuscrito de 1954, a submeter a tradição da filosofia política a uma crítica radical que abra o caminho para uma nova filosofia política capaz de fazer da pluralidade objeto do seu espanto. Enquanto o filósofo político se identificar com aquele que "põe ordem no hospício" (Arendt, 1993a, p. 74) o seu desejo de ordem continuará a impedi-lo de compreender os assuntos humanos que não se vergam aos seus padrões. Por isso ele aniquila a pluralidade, começando a fazer isso consigo mesmo. Compreender, para Arendt, é alguma coisa bastante distinta de ordenar, regular, submeter a regras. Mas a filosofia tem um impulso dominante para "pôr ordem nas coisas do mundo que não podem ser apreendidas ou julgadas sem estar submetidas ao crivo de algum princípio transcendente" (idem,

sem nada fazer, sem desempenho de feitos ou realização de obras (works). "Assim, a atitude mais adequada dos mortais, uma vez que houvessem atingido a vizinhança do imortal, era a contemplação inativa e muda [speechless]", afinal tanto o noús aristotélico quanto a verdade platônica não podiam ser apreendidos ou traduzidos em palavras (Arendt, 1992, p. 77).

10 Arendt detecta a fundamentação da ação e do pensamento na faculdade do discurso em Sócrates e, além disso, a considera uma característica da cultura grega, com a qual Platão e Aristóteles rivalizam ao eleger a contemplação como a forma mais elevada de vida, em detrimento da ação e do discurso. Para ela, Sócrates estava mais de acordo, nesse aspecto, com a cultura grega do que os seus sucessores filósofos, que rompem com ela ao passarem a identificar a imortalização com a contemplação e não mais com grande feitos e palavras. 
pp. 78-9). Daí ela desconfiar que haja mesmo uma contradição inerente entre a filosofia e a política, a ponto de não se identificar como filósofa. ${ }^{11}$ A sua filosofia política, se é que ela aceitaria algo nesses termos, quer ser menos ordenadora e quer abolir a expectativa de encontrar $a$ verdade, condição sine qua non para se abrir para a pluralidade humana. Isso implica recusar o modelo da fabricação, que pretende, justamente, reduzir as “calamidades” da ação (voltarei a isso seguir). No prefácio escrito em 1950 para As origens do totalitarismo, ela diz que compreender "não significa negar o chocante, deduzir o que é sem precedentes do precedente", não significa diminuir "o impacto da realidade e o choque da experiência” (Arendt, 2004, p. 12). ${ }^{12}$ Compreender significa encarar a realidade sem preconceitos. Isso se relaciona de perto com a necessidade de questionar o antagonismo entre verdade e opinião, de se distanciar de toda e qualquer solução teórica que resolva os "dilemas da ação como se fossem problemas de cognição” (Arendt, 2014, p. 276) e recusar soluções "progressistas" e positivistas que descartam, como se fossem irrelevantes, as perguntas que não têm resposta evidente ou demonstrável (Arendt, 1954, imagem 65). Considerando-se ou não uma filósofa, Arendt parece sim almejar uma filosofia política livre de excessos racionalistas. E seria bom ao filósofo que começasse a abandonar a expectativa de dominar tiranicamente o seu próprio corpo e a matar a pluralidade que existe dentro de si. Isso, claro, se almeja tornar a filosofia significativa para a política e vice-versa.

Para Arendt, essa expectativa do filósofo de governar a si mesmo se expressa, ao longo da história do pensamento, no ideal da autolegislação e da soberania de si. Seja lá como esse ideal se manifeste ao longo da história da filosofia - como autonomia, soberania, autogoverno - em geral ocorre em detrimento da pluralidade interna do self, da sua concretude, da sua corporeidade e das circunstâncias em que se encontra e age.

Ao perguntar-se, em $A$ vida do espírito, sobre "o que nos faz pensar", Arendt procura um modelo e o encontra, novamente, em Sócrates, um pensador não profissional, que unifica em sua pessoa duas paixões aparentemente contraditórias: a de pensar e a de agir. Essa união não se manifesta precisamente na aplicação do pensamento à ação ou na aplicação de padrões teóricos à ação. O Sócrates da Arendt está, diferentemente dos pensadores profissionais, mais confortável em passar de um campo ao outro. Sócrates é o modelo porque Arendt encontra nele o avanço e o recuo constante entre o mundo das aparências e a necessidade de refletir sobre esse mundo (Arendt, 2002, p. 126). A filósofa não profissional que Arendt busca é, assim me parece, alguém que não tem a pretensão da verdade, de ordenar e que tampouco

11 “Eu não pertenço ao círculo dos filósofos. Meu ofício - para me exprimir de uma maneira geral - é a teoria política. Não me sinto em absoluto uma filósofa, nem creio que seria aceita no círculo dos filósofos (...)”, diz ela em entrevista a Günter Gauss em 1964 (Arendt, 1993b, p. 123.)

12 Tradução modificada de acordo com o original (cf. Arendt, 1958, p. viii). 
se submeta docilmente às regras: em resumo, um pensador que tenha permanecido sempre um homem entre homens, que nunca tenha evitado a praça pública e tenha sido um cidadão entre cidadãos, que não tenha feito nem reivindicado nada além do que, em sua opinião, qualquer cidadão poderia e deveria reivindicar (idem, ibidem).

Parece, assim, que a filosofia política talvez deixe de ser uma contradição em termos se a filósofa abandonar a pretensão de admirar de cima o espetáculo ou de colocar ordem no hospício com padrões estabelecidos do lado de fora, numa região imune à realidade. Faço algumas observações. (1) Nota-se que Arendt não recusa, evidentemente, a diferença entre pensamento e ação e tampouco nega que o pensamento exija um certo afastamento do mundo e das coisas para ser realizado. O que ela está criticando é que a filosofia tenha a tarefa de estabelecer padrões "verdadeiros" e aplicá-los à ação. Pensamento e ação dialogam de alguma maneira não muito precisa, deve-se reconhecer, quando a sua tarefa (e quando a tarefa da filosofia) não é exatamente a aplicação de padrões teóricos à ação: Sócrates transita nesses dois campos, avança e recua constantemente entre o mundo das aparências e a necessidade de refletir sobre ele. 0 pensamento político parte do mundo das aparências e a ele retorna, emerge dos incidentes da "experiência viva e a eles deve permanecer ligado, já que são os únicos marcos por onde pode obter orientação" (Arendt, 1992, p. 41, grifo meu). A primazia da aparência é um fato inegável do qual o filósofo não pode escapar e ao qual tem sempre que voltar (Arendt, 2002, p. 21). ${ }^{13}$ 2) Arendt, enfaticamente crítica do filósofo no Olimpo, quer que ele ou ela sejam um entre tantos outros, imersos na pluralidade. Ao colocá-los na "praça pública", Arendt parece querer também desfazer o abismo que normalmente os separa das pessoas comuns, que também são capazes de pensar. Ela tinha uma firme confiança na capacidade das pessoas em geral de refletir criticamente e agir, e aprendeu com Jaspers que "tanto a filosofia como a política dizem respeito a todos" (Arendt, 2003, p. 70). (3) A filósofa, que não veio para aplicar padrões, tampouco se submete docilmente às regras vigentes. O pensamento, ao buscar o significado daqueles "conceitos" com os quais lidamos cotidianamente, opera uma desestabilização do que está dado. Quando buscamos definir as palavras que fazem parte da nossa fala cotidiana e quando começamos a discutir o seu significado, "nada mais fica no lugar, tudo começa a mover-se” (Arendt, 2002, p. 128). Com uma metáfora, Arendt explica que o pensamento degela palavras que no uso cotidiano têm as suas medidas ocultas

13 Uma das mais perniciosas falácias filosóficas é, portanto, o solipsismo, que encerra o pensador nele mesmo e o leva a viver completamente no singular (Arendt, 2002, p. 37). 0 preço para retira-se da "completa bestialidade da multidão" é a instauração de um subjetivismo radical. A figura central dessa história, na modernidade, é Descartes, que com a sua res cogitans inventou uma "criatura fictícia, sem corpo, sem sentidos", que abandonou o mundo a ponto de sequer saber se existe uma distinção entre o real e o irreal (idem, p. 38). Rejeitando inteiramente essa ficção, Arendt reafirma não apenas que quem pensa é uma criatura real e corporificada, mas também que o seu pensamento está diretamente atado à sua biografia, às suas experiências pessoais e que o filósofo político é alguém que está no espaço público, na "praça do mercado". 
e por isso se aplicam a diversas coisas e contextos (idem, p.129). Nesse sentido, uma vez que o pensamento degela o que a linguagem congelou, ele tem um efeito destrutivo dos critérios estabelecidos, dos valores, dos padrões, dos costumes e das regras de conduta (idem, p. 131). Esse exercício de reflexão, que é discursivo, sai em busca de significado e não da verdade. Mas mesmo sem descortinar a verdade (e por isso mesmo) e sem nos prover com “convicções” ou definições definitivas para guiar a nossa conduta futura, o pensamento tem, para Sócrates, a potência de nos tornar melhores em alguma medida. ${ }^{14}$ Pensar e falar sobre a piedade, a justiça, coragem pode tornar as pessoas mais piedosas, mais justas, mais corajosas. ${ }^{15}$ Por isso Sócrates se autorreconhecia como um moscardo ou como uma parteira. Como moscardo, transmite a sua perplexidade aos outros, os provoca a pensar, contesta a sua docilidade diante do que está dado e repetido no uso cotidiano. Como parteira, não mostra a verdade, mas purga os preconceitos que nos impedem de pensar. Falando de Sócrates como quem fala de si mesma, Arendt sublinha que, ao contrário dos filósofos profissionais, ele sente "a necessidade de verificar com seus semelhantes se suas perplexidades também eram por eles compartilhadas e isso é completamente diferente de encontrar soluções para enigmas e, então, demonstrá-los aos outros” (idem, p. 130). A condição para o filósofo sair da torre de

14 Em 1972, no famoso Colóquio de Toronto, ao responder a uma pergunta sobre como avalia a sua tarefa enquanto teórica política, Arendt recusa terminantemente a missão de doutrinar pessoas e diz que a sua expectativa é tão somente despertá-las para o pensamento: "Não posso dizer explicitamente a você - e detestaria fazer isso - quais as consequências na política real deste tipo de pensamento que eu experimento, não para doutrinar, mas para instigar e despertar os meus alunos. Posso imaginar muito bem que um torne-se republicano e o outro liberal ou Deus sabe o quê. Mas de uma coisa eu tenho esperança: de que certas coisas extremas, que são a consequência efetiva do não pensar (...) que essas consequências não tenham condição de vir a surgir" (Hill, 1979, p. 131. Utilizei a tradução de Adriano Correia em Arendt, 2010). Ao longo da sua vida e desde a investigação empreendida em As origens do totalitarismo até o caso Eichmann, Arendt entendeu que o totalitarismo e a sua extrema violência estavam vinculados ao bloqueio da capacidade do pensamento: a falta de pensamento pode levar a coisas extremas e à mais absoluta desumanização. À professora não cabe doutrinar pessoas para serem republicanas ou liberais e tampouco instruí-las para a ação, mas sim, como o moscardo Sócrates, instigar a atividade do pensamento e a busca incessante de compreender, que nos vincula aos outros e ao mundo das aparências e nos incita a questionar padrões (e não propriamente a assumir convicções).

15 Seyla Benhabib questiona Arendt a respeito da relação entre o pensamento e a conduta moral. Ora, sugere ela, se Heidegger "pensava", parece que a vinculação entre pensar e agir moralmente não é nada segura, afinal ele aderiu ao nazismo (Benhabib, 2000, p. 192). No entanto, parece-me que Benhabib se equivoca por desentender que não é qualquer tipo de pensamento que se relaciona com a ação moral, mas aquele que versa sobre as questões morais, sobre o comportamento, sobre estar efetivamente no mundo com os outros. Refletir sobre a nossa conduta com os outros é que pode ter algum impacto na ação. Portanto, não se trata, como Benhabib sugere, de um problema de falta de conhecimento ou de falta de cognição (cf. idem, p. 193), pois Arendt está falando de outra habilidade humana: a de pensar sobre a conduta, buscando o seu significado. Não parece ser o caso de Heidegger. Deve-se notar ainda que Arendt não estabelece uma relação mecânica entre a reflexão e a ação, nem as trata a partir de uma relação de causa e efeito. 0 que Arendt supõe é que, ao pensar sobre o que fazemos, temos a chance de nos distanciarmos criticamente justamente das condutas mecanizadas e impensadas e das nossas convicções, o que tem um efeito libertador inclusive para o juízo. 
marfim da mera contemplação é a comunicação com os outros. Isso Arendt encontra em Sócrates e também em Jaspers, que concebe a verdade como comunicação e, assim, torna o pensamento prático (ainda que não pragmático), isto é, "uma prática entre homens, não o desempenho de um indivíduo em sua solidão auto-escolhida" (Arendt, 2003, p. 79). ${ }^{16}$ Curiosa imagem essa da filósofa: alguém que se preocupa com a serventia do pensamento, mas não tem respostas bem definidas e pragmáticas (Arendt, 2002, p. 131). O que parece que ela pode fazer é despertar os outros e com eles refletir criticamente sobre o que está dado. Este pensamento crítico tem poder de resistência, mas para atingi-lo é preciso abdicar do Olimpo. ${ }^{17}$

Em harmonia com as consequências que extrai da sua análise da filosofia socrática em "Philosophy and Politics", Arendt formula posteriormente aquela que, na minha interpretação, é a sua solução filosófica mais potente e promissora para o problema do antagonismo entre filosofia e política. Mencionei anteriormente que Arendt encontra em Sócrates algo análogo ao que encontra no juízo de gosto kantiano: se a opinião, para Sócrates, não pode ser "algo absoluto e válido para todos", tampouco é "fantasia subjetiva e arbitrariedade”. O processo de formação conjunta e dialógica da opinião é também um processo de depuração que embora jamais alcance "a verdade" ou mesmo que não atinja o consenso pode, ainda assim, torná-la menos arbitrária, menos idiossincrática e subjetiva. Para tanto é imprescindível ouvir os outros e procurar compreendê-los. A disposição para a escuta e para a compreensão do outro e do lugar do qual ele fala é imprescindível para que possamos conviver com os outros em um mundo plural. Em Entre o passado e o futuro, novamente às voltas com Platão, que invoca a força coerciva da verdade para controlar a política, Arendt afirma que do "ponto de vista da política, a verdade tem um caráter despótico” (Arendt, 1992, p. 298). Platão não estava interessado, segundo ela, em limitar o poder político por uma Constituição, um conjunto de

16 Para uma belíssima análise da relação intelectual entre Arendt e Jasper, que sublinha com precisão e de maneira inovadora a importância dele para o pensamento político dela, conferir a tese de doutorado de Igor Vinícius Basílio Nunes, In Between - o mundo comum entre Hannah Arendt e Karl Jaspers: da existência política ao exemplo moral (Nunes, 2018).

17 Arendt sabe perfeitamente que pensar (nesses termos) é um empreendimento perigoso, daí ser mais seguro trabalhar com padrões e aplicá-los ou subsumir casos particulares a regras gerais ou universais. Abandonar a expectativa da verdade pode municiar os cínicos, os céticos, os irracionalistas e os niilistas. Que se tome o exemplo de Alcebíades para o cínico, que "aprendeu" a pensar sem uma doutrina e transformou os não-resultados da investigação socrática em um resultado negativo: "se não podemos definir o que é a piedade, sejamos ímpios" (Arendt, 2002, p. 132). Em Entre o passado e o futuro, Arendt alerta, dessa vez através de Cícero, para o perigo oposto do platonismo, que é o irracionalismo. Ela é clara em defender que a rejeição do ideal da verdade coerciva não deve levar à adesão ao irracionalismo (Arendt, 1992, p. 279), assim como a crítica a Platão não será adequada se escorregar para o niilismo, que nega os valores estabelecidos, mas permanece ligado a eles, sem o saber (Arendt, 2002, p. 132). A filosofia política de Arendt encontra-se em um intervalo entre um racionalismo exacerbado e o irracionalismo. 0 ponto é que para rejeitar o irracionalismo não é preciso abraçar o erro diametralmente oposto, que é o racionalismo extremado, que torna o pensamento sem sentido e desatado da experiência e do particular. 
direitos ou pelo sistema de controles e equilíbrios (como faz Montesquieu), mas sim pela verdade, algo que emerge do exterior, que tem origem fora do campo político e que é totalmente independente das aspirações e desejos dos cidadãos. A resposta dela, repetindo o que já havia dito em "Philosophy and Politics", é que o debate constitui a essência da vida política:

Os modos de pensamento e de comunicação que tratam com a verdade, quando vistos da perspectiva política, são necessariamente tiranizantes; eles não levam em conta as opiniões das demais pessoas e tomá-las em consideração é característico de todo pensamento estritamente político (idem, p. 299).

0 pensamento político, eis a tese de Arendt, é representativo: eu formo a minha opinião considerando "um dado tema de diferentes pontos de vista, fazendo presentes em minha mente as posições dos que estão ausentes” (idem, ibidem). Não se trata de empatia, de procurar ser ou sentir como a outra pessoa, mas de buscar considerá-la ao formar a minha opinião e o meu juízo. Formar a opinião requer levar a perspectiva dos outros em consideração e quanto “mais posições de pessoas eu tiver presente em minha mente ao ponderar um dado problema, e quanto melhor puder imaginar como eu sentiria e pensaria se estivesse em seu lugar, mais forte será a minha capacidade de pensamento representativo e mais válidas as minhas conclusões finais, a minha opinião" (idem, ibidem, grifo meu). Arendt encontra na primeira parte da Crítica do juízo de Kant inspiração para resolver o antagonismo clássico entre a verdade e a opinião (tornando o pensamento político representativo) e entre o universal e o particular.

A filosofia, com os seus universais, não encontra um lugar para o particular e o que Arendt vislumbra no juízo de gosto kantiano é justamente a possibilidade de recuperar (filosoficamente) a dignidade do particular (cf. Benhabib, 1990). Para ela, que nisso se declara partidária de Aristóteles, é um erro procurar os universais - "coisas que não podem ser localizadas" - no campo dos assuntos políticos, que é por definição o domínio do particular (Arendt, 2002, p. 151). Isso não significa condenar o campo da política à mais absoluta arbitrariedade do particular (seja de perspectivas estritamente individuais ou coletivas), mas almejar que o "geral" (não o universal) possa emergir do pensamento representativo, que leva a perspectiva dos outros em consideração:

Em matéria de opinião, mas não em matéria de verdade, nosso pensamento é verdadeiramente discursivo, correndo, por assim dizer, de um lugar para o outro, de uma parte do mundo para outra, através de todas as concepções conflitantes, até finalmente ascender dessas particularidades a alguma generalidade imparcial (Arendt, 1992, p. 300, grifo meu).

O geral é conquistado quando um tema é "forçado ao campo aberto" no qual pode ser visto de todos os lados, em todas as perspectivas particulares possíveis. 
Não basta ao pensamento estar em concordância consigo mesmo para que sejamos capazes de viver com os outros. É preciso, como anteviu Kant na Crítica do juízo, que sejamos capazes de pensar no lugar das outras pessoas com as quais esperamos obter algum acordo:

a eficácia do juízo repousa em uma concordância potencial com os outros e o processo pensante, que é ativo no juízo de algo, não é, como o processo de pensamento de raciocínio puro, um diálogo de mim para comigo mesma, porém se acha sempre e fundamentalmente (...) em antecipada comunicação com os outros com quem eu sei que devo afinal chegar a algum acordo (idem, p. 247, tradução modificada).

Nota-se que a validade do juízo - isto é, a validade do juízo em um mundo plural - depende de que as pessoas sejam capazes de se libertar das condições subjetivas privadas que determinam o seu modo de ver na intimidade, mas não têm validade no domínio público. A mentalidade alargada garante um lugar para o particular (para a particularidade do outro) ao mesmo tempo em que permite que o juízo transcenda as limitações estritamente individuais. Por isso ela não pode funcionar em estrito isolamento e solidão, "mas necessita da presença de outros 'em cujo lugar' cumpre pensar” (idem, p. 275). o juízo depende da presença dos outros para ser válido: se a sua validade nunca é universal é porque ele é feito por pessoas concretas e particulares levando em consideração a perspectiva dos outros presentes, igualmente concretos e particulares. Com ele nos ajustamos a um mundo comum: o juízo é a mais importante atividade para que possamos compartilhar o mundo (idem, p. 276) sem precisarmos recorrer a uma verdade coercitiva, a uma razão legisladora, a um imperativo categórico, que operam, sempre, em detrimento do particular e da pluralidade de perspectivas.

Entendo que a mentalidade alargada é a mentalidade condizente com a vida democrática que Arendt almeja. ${ }^{18}$ Embora ela não tenha sistematizado as suas conclusões a respeito das condições da democracia (ela preferia chamar de "república”), a sua obra se torna mais potente e interessante quando procuramos alinhavar os fios que ela deixa dispersos e pensar a relação entre essa apropriação sui generis do juízo de gosto kantiano com a ideia da formação dialógica da opinião,

18 A mentalidade alargada é a antítese da mentalidade do homem hobbesiano, à qual Arendt se opõe duramente em As origens do totalitarismo: contra a mentalidade exclusivamente autointeressada do indivíduo burguês supostamente retratado por Hobbes, Arendt defende uma mentalidade que seja capaz de transcender as condições subjetivas privadas para levar os outros em consideração; contra o juízo do homem hobbesiano, baseado no ponto de vista individual ou de uma minoria, Arendt defende que o juízo somente será capaz de nos orientar no domínio público e no mundo comum se considerar amplamente a perspectiva das outras pessoas. Ao tornar o princípio do benefício próprio uma característica inelutável da natureza humana, Hobbes nos deixou apenas duas possibilidades: a guerra generalizada de todos contra todos ou a formação de um Estado aos moldes do Leviatã. Em contrapartida, ao apostar que a formação do juízo seja capaz de transcender as limitações estritamente individuais, Arendt nos diz que a vida política nos reserva algo mais do que a relação de comando e subordinação (cf. Arendt, 2004, pp.164-176. 
com a crítica da redução do político ao jurídico e à representação política, com o seu elogio do sistema de conselhos, das instituições participativas e com a valorização de uma cultura democrática que fomenta a disposição para o discurso argumentativo, o prazer de agir, o prazer de estar como os outros diferentes e o espírito público. A definição de liberdade como participação política e a defesa inconteste da democracia participativa feita por Arendt em Sobre a revolução ${ }^{19}$ se tornam mais interessantes quando pensadas à luz da convicção de que o diálogo pode melhorar as pessoas e os cidadãos, de que o pensamento político depende da presença dos outros (e, portanto, é fruto de um aprendizado), de que o exercício do diálogo nos provoca a pensar e pensar nos convoca a contestar as regras e os padrões que seguimos acriticamente. Os fios dispersos da obra arendtiana se alinhavam pela ideia de que o debate é a essência da vida política.

Mas todos esses aspectos do seu pensamento político - mentalidade alargada, cidadania participativa, cultura democrática vinculada à prática da autogestão se veem colocados na camisa de força da distinção excessivamente rígida entre o político e o social (e entre o público e o privado) que ela estabelece em $A$ condição humana e repete em Sobre a revolução. ${ }^{20}$ Vimos na primeira parte desse texto que ela censura duramente a tradição da filosofia política por erigir o modelo de atividade como fabricação em detrimento da ação. Vimos também o esforço que ela faz para recuperar a dignidade da ação, do discurso, do particular, do juízo e da opinião contra as limitações impostas pela fabricação, pelos falsos universais e pela coerção da verdade. Aqui estão, em minha interpretação, os potenciais democráticos do pensamento arendtiano, que emergem do seu enfrentamento teórico com a hostilidade da filosofia contra a pluralidade e as vicissitudes dos assuntos humanos. No entanto, ao separar rigidamente o social e o político, Arendt coloca um freio no que parecia ser um projeto radicalmente democrático.

Para resolver o problema que detecta na tradição de privilegiar o modelo de ação como fabricação, Arendt propõe, em A condição humana, uma distinção entre três tipos de atividades humanas: trabalho, obra e ação. Contra a ideia exposta por Marx, em A ideologia Alemã, de que o que os indivíduos são "coincide com a sua produção, isto é, tanto com o que eles produzem quanto como a maneira como produzem" (Marx \& Engels, 2002, p.11), Arendt defende uma diferenciação entre o trabalho e a obra - o primeiro ligado à satisfação das necessidades vitais e a

19 Trato mais demoradamente deste tema no artigo "Liberdade política e cultura democrática em Hannah Arendt" (Frateschi, 2016).

20 A distinção rígida entre o social e o político dá margem à objeção de Habermas de que ao recusar a intrusão de questões sociais e econômicas na esfera pública, Arendt se torna "vítima de um conceito de política que é inaplicável às condições modernas" (Habermas, 1977, p.14). Ao separar a práxis das atividades não políticas do trabalho e da obra, Arendt restringe o poder político à ação comunicativa pagando o preço de tirar a ação estratégica do âmbito da política de remover a política da sua relação com o ambiente econômico e social (idem, p. 16). 
segunda à construção de um mundo artificial - e, mais importante, entre essas duas atividades e a ação: "a única atividade que ocorre diretamente entre os homens sem a mediação das coisas e da matéria" e que corresponde à condição humana da pluralidade (Arendt, 2014, p.8).

As três atividades humanas são fundamentais e complementares: o trabalho garante a vida (trata-se da atividade que corresponde ao processo biológico do corpo humano), a obra proporciona um mundo artificial durável, a ação possibilita a vida política (idem, pp.8-11; 217). Com essa distinção, Arendt pretende corrigir a rota imposta pela modernidade e consolidada com Marx de privilegiar o trabalho e considerá-lo como obra. Segundo ela, Marx trata o animal laborans como se fosse o homo faber (idem, pp.107-8), glorificando indevidamente o trabalho e confundindo-o com uma atividade criativa quando o que ele garante é apenas o processo vital, a subsistência (idem, p. 109). Ainda mais, perde-se a ação quando o homem é reduzido ao animal laborans: a política depende de uma pluralidade de perspectivas, que não se reduzem a interesses e questões materiais. O erro do materialismo é ignorar "a inevitabilidade com que os homens se desvelam como sujeitos, como pessoas distintas e singulares" (idem, p. 229). Podemos compreender a definição arendtiana de ação atividade que ocorre diretamente entre os homens, sem a mediação das coisas ou da matéria, - como reação à ideia de que o que os homens são depende das condições materiais de produção e como reação à tradição em geral que privilegia o modelo de atividade como fabricação: recuperar a dignidade da política implica reestabelecer a sua especificidade em relação à racionalidade instrumental e econômica e em relação ao modelo da fabricação.

Entendo que essa tipologia das atividades proposta por Arendt tem uma função primordialmente crítica e visa fazer com que ação e discurso apareçam como características definidoras da política, algo que foi perdido desde que Platão deu o seu acorde fundamental, tornando a ação e o discurso totalmente prescindíveis precisamente para eliminar do domínio dos assuntos humanos o seu caráter de instabilidade e fragilidade. Mais ainda. A recusa de que as questões materiais (sociais e econômicas) esgotem o campo da política pode ser lida como um avanço teórico importante, na medida em que abre espaço para aceitarmos como relevantes outras formas de relação e de sujeição que não se reduzem às relações econômicas e materiais. Quando Arendt censura Marx pela sua suposição de que uma vez resolvida a luta de classes a justiça e a liberdade se instalariam de uma vez por todas, ela abre caminho para uma reflexão mais ampla e complexa a respeito dos conflitos sociais, que não teriam uma causa primordial que, uma vez eliminada, viveríamos em perfeita harmonia. Teorias feministas, sobretudo a partir dos anos 1980, partem do mesmo pressuposto e passam a considerar outros fatores da sujeição de indivíduos e grupos, tais como (além da classe) gênero e raça. A ideia de que a sujeição e 
a subalternidade são melhor compreendidas à luz de um sistema interligado de opressões (e que informa o conceito de interseccionalidade) se beneficia justamente da recusa de que o fator classe seja o único a ser levado em consideração. No entanto, Arendt extrai daquela tipologia das atividades uma diferenciação de tal modo rígida entre o social e o político (e entre o privado e o público) que, nesse aspecto, a sua rebelião contra a tradição finda em autoderrota. Ao tentar limpar o campo da política das questões materiais, ela termina por desmerecer o marcador classe, o que a leva a uma análise precária das relações de poder. Ao mesmo tempo, ao separar em campos aparentemente incomunicáveis o privado e o público, ela tende a vetar que questões tradicionalmente consideradas privadas adentrem o espaço público e sejam objeto de problematização e debate entre os cidadãos. ${ }^{21}$ Ela censura Platão por ter desejado controlar a política com um critério "independente das aspirações e desejos dos cidadãos” (Arendt, 1992, p. 298). A distinção entre o social e o político repete o mesmo erro. Nesse aspecto, Arendt continua o acorde fundamental soado por Platão, bloqueando demandas diversas por emancipação. Repete, a contragosto, o mesmo erro que detecta também no materialismo: o de ignorar "a inevitabilidade com que os homens se desvelam como sujeitos, como pessoas distintas e singulares" (Arendt, 2014, p. 229). Podemos perguntar a ela: como as pessoas podem aparecer no espaço público como distintas e singulares se certas questões relativas justamente à sua distinção e à sua singularidade não têm dignidade suficiente para serem objeto de debate público?

Buscando reconciliar a filosofia com a política, Arendt dá um passo filosófico extraordinário ao afirmar que a disposição para a escuta e para a compreensão do outro e do lugar do qual ele fala é imprescindível para que possamos compreender os outros diferentes, na sua concretude e especificidade. Mas ao colocar um muro entre o social e o político e entre o privado e o público a sua própria capacidade de escuta parece bloqueada, como se ela - a teórica - já tivesse decidido de antemão o que é ou não digno de ser dito e ouvido no espaço público. Justo Arendt que na sua rebelião contra o filósofo no Olimpo havia rejeitado que à filosofia coubesse estabelecer padrões rígidos e aplicá-los à ação. Mas como ela mesma diz a respeito de Marx: grandes filósofos não estão imunes a grandes contradições. Se Arendt trai as suas promessas, cabe a nós pensarmos com ela e contra ela para continuarmos a buscar um modo de conciliar a filosofia com a pluralidade humana.

\section{Referências}

Arendt, H. (1954). "Philosophy and Politics: the problem of action and thought after the French Revolution" lecture, 1954 (3 of 4 folders). In: Hannah Arendt Papers,

21 Para uma crítica contundente e acertada da separação entre o social e o político e entre o público e o privado, conferir The reluctant modernism of Hannah Arendt, capítulo 5 (Benhabib, 2000). 
Manuscript Division, Library of Congress, Washington, D.C . (1958). The origins of totalitarianism. Cleveland: Meridian Books. - (1992). Entre o passado e o futuro. São Paulo: Editora Perspectiva. (1993). “O grande jogo do mundo". In: A dignidade da Política. Rio de Janeiro: Relume-Dumará.

(1993a). "O interesse pela política no recente pensamento filosófico europeu”. In: A dignidade da Política. Rio de Janeiro: Relume-Dumará, - (1993b). "Só permanece a língua materna". In: A dignidade da Política. Rio de Janeiro: Relume-Dumará. . (2002). A vida do Espírito. Rio de Janeiro: Relume Dumará.

Letras. - (2003). Homens em Tempos Sombrios. São Paulo: Companhia das - (2004). As origens do totalitarismo. São Paulo: Companhia das Letras. . (2008). “O Fim da tradição”. In: A promessa da política. Rio de Janeiro: Difel.

- (2010). Sobre Hannah Arendt. Tradução de Adriano Correia. Inquietude, Goiânia, 1(2), ago/dez. 2010.

- (2014). A condição humana. Tradução Roberto Raposo. Revisão e apresentação Adriano Correia. São Paulo: Forense Universitária.

Benhabib, S. (1990). Hannah Arendt and the redemptive power of narrative. Social Research, 57(1) (Spring 1990).

. (2000). The reluctant modernism of Hannah Arendt. Oxford: Rowman \& Littlefield Publishers.

Frateschi, Y (2016). Liberdade política e cultura democrática em Hannah Arendt. Cadernos De Filosofia Alemã, 21(3), pp. 29-50.

Habermas, J (1977). Hannah Arendt's Communications Concept of Power. Social Research, 44(1) pp. 3-24.

Hill, M (1979). Hannah Arendt: the memory of the public world. New York: St. Martin's Press.

Marx, K. \& Engels, F. (2002) A ideologia alemã. São Paulo: Martins Fontes.

Nunes, I. (2018). In Between - o mundo comum entre Hannah Arendt e Karl Jaspers: da existência política ao exemplo moral. Tese de Doutorado. Instituto de Filosofia e Ciências Humanas, Universidade Estadual de Campinas, Campinas, SP. 